\title{
RECTAL ENZYMES OF ATTINE ANTS. $\alpha$-AMYLASE AND CHITINASE
}

\author{
IMICHAEL M. MARTIN, MARY J. GIESELMANN, and \\ JOAN STADLER MARTIN
}

The Departments of Chemistry and Zoology, University of Michigan, Ann Arbor, Michigan 48104, U.S.A.

(Received 1 fanuary 1973)

\begin{abstract}
The faecal material of seven species of attine ants from the genera Cyphomyrmex, Apterostigma, Myrmicocrypta, Sericomyrmex, and Atta has been shown to contain $\alpha$-amylase and chitinase, but only a trace of uricase. Chitinase probably serves a beneficial rôle in the fungus-culturing activities of the primitive forms by contributing to the degradation of chitinous substrates, such as insect cuticle, and by lysing potentially competitive chitinous fungi. Biochemical factors significant in the evolution of the fungus-growing ants are discussed.
\end{abstract}

\section{INTRODUCTION}

The Attine ants culture a fungus in their nests and exploit this fungus as their primary and probably sole food source (BeLt, 1874; MülleR, 1874; WheELer, 1907; WEBER, 1972). In culturing their fungi, ants of all attine species characteristically defaecate on their fungus gardens and on substrate which they are preparing for incorporation into their gardens (HUBER, 1905; WEBER, 1972). In previous papers we have reported that the faecal material of the attine ants contains proteolytic enzymes (MarTin and MarTin, 1970a, b, 1971) and further that the fungus cultured by the attine species Atta colombica tonsipes grows very poorly in a culture medium in which nitrogen is present exclusively in polypeptide form (MARTIN and Martin, 1970a). We have suggested that in those attine species which cultivate their fungi on fresh plant material, a substrate in which alpha-amino nitrogen is present largely as polypeptide, the deposition of faecal material benefits the fungus by providing a supplemental source of proteolytic enzymes, thereby compensating for an ecologically critical limitation in the metabolic machinery of the fungus.

The use of fresh plant material in the fungus gardens is a practice restricted to the advanced or specialized genera Atta, Acromyrmex, and Sericomyrmex (WEBER, 1972). The primitive fungus-growers culture their fungi on substrates such as insect faeces, insect carcasses, rotting wood, and plant debris. These substrates are very cifferent biochemically from fresh plant material, since they have already been subjected to catabolic processes, such as digestion, microbial decay, or autolytic decomposition, before incorporation into the ants' gardens. These substrates have much lower levels of polypeptide nitrogen relative to non-polymeric 
forms of reduced nitrogen, such as ammonia, amino acids, uric acid, allantoin, allantoic acid, and urea. Thus, it is evident that in the primitive attines, the faecal proteases do not serve the same critical function in fungus-culturing as is the case in the advanced forms. Indeed our discovery of protease in attine faecal fluid sheds no light upon the significance of the defaecation behaviour of the primitive forms, and provides no insight into the biochemical basis for the symbiosis between the primitive attines and their fungi.

It seems reasonable that if the attinc ants excrete proteolytic enzymes, they might excrete other enzymes as well, some of which might serve important functions in the fungus-culturing activities of the primitive forms. This paper reports the results of a study initiated to establish the presence or absence of other enzymes in the rectal fluid of fungus-growing ants. We have examined four species from the primitive genera Cyphomyrmex, Apterostigma, and Myrmicocrypta and three species from the advanced genera Sericomyrmex and Atta for activity characteristic of the three enzymes $\alpha$-amylase, uricase, and chitinase.

\section{MATERIALS AND METHODS}

\section{The ants}

Live, freshly collected ants were the source of all materials used in this study. Cyphomyrmex rimosus trinitatis, C. costatus, Apterostigma dentigerum, Myrmicocrypta ednaella, Sericomyrmex amabalis, and Atta cephalotes isthmicola were collected on Barro Colarado Island, Canal Zone, and were identified by Professor Neal Weber, Swarthmore College. A. colombia tonsipes specimens were from a colony maintained at the University of Michigan.

\section{Dissections and general procedures}

Gasters of live ants were dissected under distilled water or the buffer used in the enzyme assay. The contents of the midguts or rectums from 10 to 50 ants were removed with a fine glass capillary needle attached to a syringe. The pooled samples were kept in an ice-bath until they were assayed, at which time they were divided into two equal portions. One portion was assayed for enzymatic activity, the other was inactivated by heating at $100^{\circ} \mathrm{C}$ for $15 \mathrm{~min}$, and was used as a blank. The ratio of rectal to midgut activity was determined from samples obtained from the same ants from the expression:

$$
\frac{\text { O.D.rectal sample }}{\text { O.D.D.rectal blank }} \text {. }
$$

$\alpha-$ Amylase assay

Samples were incubated for $1 \mathrm{hr}$ at $30^{\circ} \mathrm{C}$ with $0.25 \mathrm{ml}$ of a $2 \%$ starch $-4 \%$ sodium chloride solution in $0.1 \mathrm{M}$ phosphate buffer $(\mathrm{pH} 6.5)$. The incubation was terminated by the addition of $0.25 \mathrm{ml}$ of dinitrosalicylic acid reagent and treated according to the procedure of BERNFELD (1955). 


\section{Chitinase assay}

The assay was adapted from methods of REISSIG et al. (1955) and WATERHOUSE et al. (1961). Colloidal chitin was prepared according to BeRGER and ReYNoldS (1958) and the incubations were conducted in $0.04 \mathrm{M}$ acetate buffer ( $\mathrm{pH} 5 \cdot 2$ ). The possibility that the observed chitinase activity was due to bacterial contamination during the long incubation period $(24 \mathrm{hr})$ was eliminated when the degradation of chitin was found to increase steadily with incubation time, as it should if the activity were due to enzymes initially present in the sample. Also, the results were found to be independent of the presence or absence of toluene in the incubation mixture. Assays were run routinely without added toluene.

\section{Uricase assay}

The sample, adjusted to $1 \mathrm{ml}$ with distilled water, was incubated at $37^{\circ} \mathrm{C}$ with $1 \mathrm{ml}$ of $\mathrm{C} \cdot 1 \mathrm{M}$ glycine buffer ( $\mathrm{pH} \mathrm{9.2)}$, and $1 \mathrm{ml}$ of a uric acid solution $(10 \mathrm{mg}$ of uric acid, $10 \mathrm{ml}$ of 5 to $10 \%$ lithium carbonate, $200 \mathrm{ml}$ of water). The disappearance of uric acid was followed by periodic readings of the absorption at $293 \mathrm{~nm}$ (KALCKAR, 1947).

\section{Lysozymo assay}

Proteins in the pooled rectal fluid of $350 \mathrm{~A}$.c. tonsipes were precipitated with $70 \%$ ammonium sulphate, collected by centrifugation, dialysed, and lyophilized (Powning and IRzykiewicz, 1967). The residue was taken up in $200 \mu \mathrm{l}$ of water, and the resulting solution divided in half. Lysozyme action was studied using Micrococcus lysodeikticus cells at $35^{\circ} \mathrm{C}$ at two $\mathrm{pH}$ 's $(6 \cdot 2,0.066 \mathrm{M}$ phosphate and 3.5, $0.01 \mathrm{M}$ citrate). The change in O.D. at $450 \mathrm{~nm}$ was followed for $60 \mathrm{~min}$.

\section{RESULTS}

Severı species of attine ants from 3 primitive genera (Cyphomyrmex, Apterostigma, and Myrmicocrypta) and two specialized genera (Sericomyrmex and Atta) were found to have significant $\alpha$-amylase and chitinase activity in both the midgut and the rectal fluids. The results of the assays are summarized in Table 1. Rectal to midgut activity ratios for $\alpha$-amylase, chitinase, and protease (MARTIN and MarTiN, 1970b, 1971) are summarized in Table 2. The ratio for any given enzyme shows considerable variation in different samples of ants of the same species. For example, the rectal to midgut protease activity ranges from $2: 1$ to $10: 1$ in A. c. tonsipes. It is noteworthy that in spite of this variability in the ants, the rectal to midgut ratios for $\alpha$-amylase, chitinase, and protease are of the same magnitude in any given species of attine. Those species which have higher protease activity in the rectum (Cyphomyrmex, Sericomyrmex, and Atta) also have higher, or in two cases equal, $\alpha$-amylase and chitinase activities in the rectum, whereas those species which have higher protease activity in the midgut (Apterostigma and Myrmicocrypta) also have higher $\alpha$-amylase and chitinase activities in the midgut. 
The results of the chitinase assays may indicate the presence of chitobiase in the rectal fluid as well. The product of the action of chitinase on chitin is the disaccharide, chitobiose, whereas the development of colour in the assay depends upon the production of $\mathrm{N}$-acetylglucosamine, the monosaccharide produced by the hydrolysis of chitobiose. Since no $\beta$-glucosidase was added to the incubation

TABle 1 -Measurement of $\alpha$-Amylase and Chitinase aCtivity in attine ANTS: O.D. (SAMPLE) - O.D. (BLANK)

\begin{tabular}{|c|c|c|c|c|c|c|}
\hline \multirow[b]{2}{*}{ Species } & \multicolumn{3}{|c|}{$\alpha$-Amylase } & \multicolumn{3}{|c|}{ Chitinase } \\
\hline & Ants* & Midgut & Rectum & Ants* & Midgut & Rectum \\
\hline C. costatus & 24 & $0 \cdot 158$ & $0 \cdot 148$ & 50 & - & - \\
\hline C.r.trinitatis & 24 & $0.005 \dagger$ & 0.057 & 24 & $0 \cdot 067$ & $0 \cdot 133$ \\
\hline A. dentigerum & 20 & $0 \cdot 249$ & $0 \cdot 085$ & 40 & 0.663 & $0 \cdot 270$ \\
\hline M. ednaclla & 50 & $1 \cdot 041$ & $0 \cdot 264$ & 50 & - & - \\
\hline S. amabalis & 12 & $0 \cdot 076$ & $0 \cdot 189$ & 46 & $0 \cdot 157$ & $0 \cdot 144$ \\
\hline A. c. isthmicola & - & - & 一 & 40 & 0.058 & 0.335 \\
\hline A.c.tonsipes & 10 & 0.026 & 0.192 & 40 & 0.037 & $0 \cdot 275$ \\
\hline A.c.tonsipes & 10 & $0 \cdot 043$ & $0 \cdot 154$ & - & - & - \\
\hline
\end{tabular}

* The number of ants indicated is the total number dissected. The pooled rectal or midgut contents were divided equally between sample and blank as described in Materials and Methods, where other procedural details may also be found.

† Midgut amylase activity was barely detectable. This measurement is subject to considerable uncertainty.

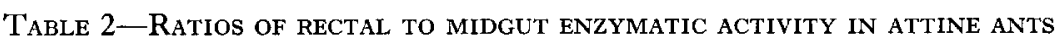

\begin{tabular}{lccc}
\hline \multicolumn{1}{c}{ Species } & $\alpha$-Amylase & Chitinase & Protease \\
\hline C. costatus & $1 \cdot 0: 1 \cdot 0$ & $>1 \cdot 0: 1 \cdot 0^{*}$ & $2 \cdot 0: 1 \cdot 0,2 \cdot 5: 1 \cdot 0$ \\
C. r. trinitatis & $24 \cdot 0: 1 \cdot 0 \dagger$ & $2 \cdot 0: 1 \cdot 0$ & $6 \cdot 0: 1 \cdot 0$ \\
A. dentigerum & $1 \cdot 0: 3 \cdot 0$ & $1 \cdot 0: 2 \cdot 5$ & $1 \cdot 0: 1 \cdot 0,1 \cdot 0: 2 \cdot 0$ \\
M. ednaella & $1 \cdot 0: 4 \cdot 0$ & $<1 \cdot 0: 1 \cdot 0^{*}$ & $1 \cdot 0: 2 \cdot 0,1 \cdot 0: 3 \cdot 5$ \\
S. amabalis & $2 \cdot 5: 1 \cdot 0$ & $1 \cdot 0: 1 \cdot 0$ & $1 \cdot 5: 1 \cdot 0$ \\
A.c. isthmicola & - & $6 \cdot 0: 1 \cdot 0$ & $5 \cdot 0: 1 \cdot 0$ \\
A.c. tonsipes & $7 \cdot 5: 1 \cdot 0,3 \cdot 5: 1 \cdot 0$ & $7 \cdot 5: 1 \cdot 0$ & $2 \cdot 0: 1 \cdot 0,5 \cdot 0: 1 \cdot 0,10 \cdot 0: 1 \cdot 0$ \\
\hline
\end{tabular}

* Due to untimely instrument failure, no spectrophotometric readings were made on the chitinase samples from $C$. costatus or $M$. ednaella. From the appearance of the assay samples, however, it was clear that in the case of $C$. costatus, there was higher activity in the rectum, whereas in the case of $M$. ednaella, there was higher activity in the midgut. We would estimate that the rectal to midgut ratios would be in the range of $2: 1$ for $C$. costatus and $1: 3$ for $M$. ednaella.

$\dagger$ The $\alpha$-amylase ratio for $C . r$. trinitatis represents a minimum value. Activity was barely detectable in the midgut.

All activity ratios have been rounded off to the nearest half integral value. 
mixture it seems likely that one was present in the rectal or midgut samples. However, since chitinase can liberate $\mathrm{N}$-acetylglucosamine directly from degraded chitin, and since the chitin used as substrate in our assay may have been partially degraded, a firm conclusion that chitobiase is present in the digestive and faecal fluids of the ants is premature.

None of the species examined had significant uricase activity in either rectal or midgut fluids. In the sample which showed the highest activity, the rectal fluid from $10 \mathrm{~A}$. c. isthmicola, uric acid was consumed at the rate of only $0.28 \mu \mathrm{g} / \mathrm{hr}$. In the blank, the rate was $0.08 \mu \mathrm{g} / \mathrm{hr}$. By contrast, in a homogenate of 10 whole gasters of this same species, the initial rate of disappearance of uric acid was $3.90 \mu \mathrm{g} / \mathrm{hr}$. Thus, while it is evident that attine ants produce uricase, at most only traces of the enzyme are released into the gut. This is not surprising, since uricase is not a digestive cnzymc, but is usually located in the fat body or Malphigian tubules of insects. Its presence in the rectal fluid was explored only because it was possible to envision a rôle for uricase in the fungus-culturing activities of the primitive attines, since many of the primitive species utilize solid insect faeces, which contain uric acid, as substrate in their gardens.

Since lysozyme-like action has often been observed in preparations of chitinolytic systems (Waterhouse et al., 1961; Thirlwell et al., 1963; Takeda et al., 1966; Powning and Irzykiewics, 1967; Landureau and Jolies, 1970), the rectal fluid of $A$. c. tonsipes was examined for its lytic properties. No lytic action against $M$. lysodeikticus cells in the rectal fluid pooled from 175 ants at either $\mathrm{pH} 3.5$ or 6.2 was detectable. This volume of rectal fluid contains a quantity of protein comparable to that found in the lysozymally active cockroach gut preparation studied by Powning and Irzykiewicz (1967). By contrast, chitinase activity was readily detectable in the rectal fluid collected from fewer than 10 ants. Thus it is clear that if the chitinase of attine rectal fluid exhibits any lysozyme-like action at all, it is extremely weak.

\section{DISCUSSION}

The main purpose of this study was to determine whether the faecal material of the fungus-growing ants contains other enzymes in addition to the proteolytic enzymes detected earlier. Clearly it does. $\alpha$-Amylase and chitinase are present in the rectal fluid of all 7 of the species examined. We suspect that further study will reveal the presence of still more enzymes in the faecal material of this tribe of ants. Since the 7 species examined have varied and diverse substrate preferences, and are from genera which represent very different stages of evolutionary development, it is evident that the excretion of faecal material containing a variety of enzymes is a general characteristic of the attines.

The three enzymes which have been detected in the faecal material of the fungus-growing ants are digestive enzymes. The midgut is their likely origin. The similar rectal to midgut activity ratios for the three enzymes in each species is compatible with the suggestion that all three originate in the midgut, and subsequently pass into the rectum where they are concentrated as a result of water 
resorption. Whereas $\alpha$-amylase and protease are widely distributed digestive enzymes in insects, chitinase has been reported as a digestive enzyme only in roaches (Waterhouse et al., 1961; Wa'tekhouse and McKellar, 1961). However, chitinase is widely distributed in the digestive fluids of other invertebrates (JEuniaux, 1966), and will probably be found to be more widely distributed in insects than is currently realized (MARTIN, MaRTIN, and GIESELMANN, unpublished results).

It seems quite likely that faecual chitinase plays a significant rôle in the fungusculturing activities of the attine ants. The primitive genera Cyphomyrmex, Mycocepurus, and Myrmicocrypta incorporate insect carcasses, the cuticle of which contains chitin, along with the vegetal matter which they use as substrate in their gardens (WEBER, 1972). The fungus grows on the surface of the insect cuticle and, judging from the mechanical fragility of such substrate, it is evident that degradation of the cuticle structure has occurred. Clearly, then, the application of chitinase to the fungus gardens, or to the substrate being prepared for incorporation into the gardens, would facilitate the metabolic utilization by the fungus of chitin present in the substrate, especially if the fungus were deficient in chitinolytic enzymes.

Chitinase would also serve to restrict the growth of other fungi in the ants' fungus gardens. Fungal cell walls are chitinous, and chitinase or chitinase plus a $\beta$ - $(1 \rightarrow 3)$-glucanase, has been observed to lyse a number of fungi (SkUjINs $e t a l$, 1965; Pramer, 1967; Domanski and Miller, 1968; Iten, 1970; Iten and Matile, 1970; Tanaka et al., 1970). The susceptibility of chitinous cell walls to the action of lytic enzymes depends upon physical and chemical properties of the wall (Potgieter and Alexander, 1966; Kuo and Alexander, 1967; Chet and Henis, 1969). Not all chitinous fungi are lysed by chitinase, but since some are, the application of chitinase to the fungus gardens would reduce the number of fungi which could grow on the substratc. This would provide a competitive advantage for any chitinase-resistant fungus, which the ants' fungus must be. Thus, the presence of chitinase suggests a beneficial rôle for the faecal material in the fungusculturing activities of the primitive attines.

The biochemical basis for the symbiosis between the attine ants and their fungi is now sufficiently well understood to allow identification of certain biochemical parameters which would have been of particular significance in the evolution of the fungus-growing ants. If the attine ants evolved from an ancestral form which supplemented its usual food sources by feeding upon fungi growing fortuitously on the remains of prey or other items of collected food, then it seems reasonable that selection would have favoured those ants which could continuously maintain reliable cultures. This could be achieved by arresting the normal process of succession at some stage when there was a flourishing growth of one dominant species. In order to perpetuate the conditions favourable to that species of fungus, the ants might adopt more specialized foraging or scavenging preferences, so that the materials brought into the nest on which the fungus would ultimately grow would be similar biochemically. The regular application of faecal material would 
serve to maintain a high moisture content in the substrate, a necessary condition for fungus growth, and also to adjust the culture medium to a more constant and reproducible composition.

If the faecal material contained residual quantities of midgut digestive enzymes, as is the case with many ants (MARTIN and MARTIN, 1970b, 1971), and one of these enzymes served an ancillary function of limiting the growth of potential fungal competitors, then selection should have favoured those ants which could excrete larger quantities of this enzyme. We suggest that residual traces of chitinase could have served this function. We do not know the fate of the digestive enzymes of non-attine ants. Nor do we know the mechanism by which the attine ants preserve their digestive enzymes from this fate, but it seems quite reasonable to assume that a mechanism which resulted in the preservation and excretion of one digestive enzyme raight result in the preservation and excretion of other digestive enzymes. Indeed, the existing primitive attine species do produce faecal material containing a numbe: of digestive enzymes, only one of which so far can be reasonably postulated to serve any useful function in fungus-culturing. Although most of the enzymes present in the faecal material of primitive fungus-growers appear to be quite extraneous, their presence in an ancestral form would have provided an evolutionary opportunity. The enzymes contributed by the ants would supplement those secreted by the fungus, and would have extended the range of substrates on which the fungus could grow. The presence of proteolytic enzymes in the faecal material appears to have been a critical factor in the change in substrate preferences from insect faeces, insect carcasses, rotting wood, and plant debris, characteristic of the primitive forms, to fresh plant material, characteristic of the specialized or advanced forms.

Acknoruledgements-We wish to thank the National Science Foundation for a grant (No. GB-31581) which supported this work. We also wish to express our appreciation to the Smithsonian Tropical Research Institute for accommodating us on Barro Colorado Island, and to NEAL. WEBER for identifying the ants.

\section{REFERENCES}

BeLt T. (1874) The Naturalist in Nicaragua. John Murray, London.

BERGER L. R. and REYNOLDS D. M. (1958) The chitinase system of a strain of Streptomyces griseus. Biochim. biophys. Acta 29, 522-534.

BerNFeld P. (1955) Amylases, $\alpha$ and $\beta$. In Methods of Enzymology (Ed. by Colowick S. P. and Kaplan N. O.), 1, 149-150. Academic Press, New York.

Chet I. and Henis Y. (1969) Effect of catechol and disodium EDTA on melanin content of hyphal and sclerotial walls of Sclerotium rolfsii and the role of melanin in the susceptibility of these walls to $\beta-(1 \rightarrow 3)$-glucanase and chitinase. Soil Biol. Biochem. 1, 131-138.

Domanski R. E. and Miller R. E. (1968) Use of a chitinase complex and $\beta$-(1,3)-glucanase for splieroplast production from Candida albicans. F. Bact. 96, 270-271.

Huber J. (1905) Über die Koloniengrundung bei Atta sexdens. Biol. Zbl. 25, 606-619, $625-6.35$.

ITEN W. (1970) Function of hydrolytic enzymes in the autolysis of Coprinus. Ber. schweiz. bot. Ges. 79, 175-198. 
Iten W. and Matile P. (1970) Role of chitinase and other lysosomal enzymes of Coprinus lagopus in the autolysis of fruiting bodies. F. gen. Microbiol. 61, 301-309.

Jeuniaux C. (1966) Chitinases. In Methods of Enzymology (Ed. by Nelfeld E. F. and Ginsburg V.), 8, 644-650. Academic Press, New York.

KaLCKar H. M. (1947) Differential spectrophotometry of purine compounds by means of specific enzymes-I. Determination of hydroxypurine compounds, F. biol. Chem. 167, $429-443$.

Kuo M. J. and Alexander M. (1967) Inhibition of the lysis of fungi by melanins. F. Bact. 94, 624-629.

Landureau J. C. and Jolles P. (1970) Lytic enzymes produced in vivo by insect cells: lysozyme or chitinase. Nature, Lond. 225, 968-969.

Martin M. M. and Martin J. S. (1970a) The biochemical basis for the symbiosis between the ant, Atta colombica tonsipes, and its food fungus. F. Insect Physiol. 16, 109-119.

Martin J. S. and MarTin M. M. (1970b) The presence of protease activity in the rectal fluid of attine ants. F. Insect Physiol. 16, 228-232.

Martin M. M. and Martin J. S. (1971) The presence of protease activity in the rectal fluid of primitive attine ants. F. Insect Physiol. 17, 1897-1906.

Müller F. (1874) The habits of various insects. Nature, Lond. 10, 102-103.

Potgieter H. J. and Alexander M. (1966) Susceptibility of several fungi to microbial lysis. F. Bact. 91, 1526-1533.

Powning R. F. and IRzykiewicz H. (1967) Lysozyme-like action of enzymes from the cockroach Periplaneta americana and from some other sources. F. Insect Physiol. 13, $1293-1299$.

Pramer D. (1967) Significant syntheses by heterotropic soil bacteria. In The Ecology of Soil Bacteria, An International Symposium (Ed. by Gray T. R. G. and Parkinson D.). Liverpool University Press, Liverpool.

Reissig J. L., Strominger J. L., and Lelorr L. F. (1955) A modified colorimetric method for the estimation of N-acetylamino sugars. F. biol. Chem. 217, 959-966.

Skujins J. J., Potgieter H. S., and Alexander M. (1965) Dissolution of fungal cell walls by a streptomycete chitinase and $\beta-(1 \rightarrow 3)$-glucanase. Archs Biochem. Biophys. 111, $358-364$.

'Takeda H., Strasdine G. A., Whitaker D. R., and Roy C. (1966) Lytic enzymes in the digestive juice of Helix pomatia. Chitinases and muramidases. Can. F. Biochem. 44, 509-518.

Tanaka H., Ogasawara N., Nakajima T., and Tamari K. (1970) Cell walls of Piricularia oryzae-I. Selective enzymolysis of Pericularia oryzae walls by wall-lytic enzymes of Bacillus circulans WL12. F. gen. appl. Microbiol., Tokyo 16, 39-60.

Thirlwell M. P., Strasdine G. A., and Whitaker D. R. (1963) A comparison of hydrolase and lytic activities of the digestive juices of the giant African snail Archatina fulica and Helix pomatia. Can. F. Biochem. Physiol. 41, 1603-1610.

Waterhouse D. F., Hackman R. H., and McKellar J. W. (1961) An investigation of chitinase activity in cockroach and termite extracts. F. Insect Physiol. 6, 96-112.

Waterhouse D. F. and McKellar J. W. (1961) The distribution of chitinase activity in the body of the American cockroach. F. Insect Physiol. 6, 185-195.

Weber N. A. (1972) Gardening ants, the Attines. Mem. Am. phil. Soc. 92, 1-146.

WheELer W. M. (1907) The fungus-growing ants of North America. Bull. Am. Mus. nat. Hist. 23, 669-807. 